\title{
Índice de masa corporal no está asociado con la oxidación de los lípidos y carbohidratos en pacientes hospitalizados
}

\author{
The body mass index is not associated \\ with lipid or carbohydrate oxidation \\ in hospitalized patients
}

\begin{abstract}
Introduction: Energy balance is influenced by the oxidation of macronutrients (proteins, carbohydrates and lipids). Objective: To characterize substrate utilization in normal weight and obese. Subjects and Methods: Bioelectrical impedance analysis and indirect calorimetry were used to determine the oxidation of carbohydrates and lipids in hospitalized patients. Subjects were divided into three groups: group 1: BMI 18.5-24.9 kg / m, group 2: BMI 25-29.9 kg/ $\mathrm{m}$ and Group 3: BMl> $30 \mathrm{k} / \mathrm{m}^{2}$. Groups of individuals were compared using ANOVA and, in some cases, after the Dunn test was applied ( $p<0.05$ were considered significant). Results: 38 individuals (11 men and 27 women) with a mean age of $44.3 \pm 16.5$ years of which 18 were eutrophic, 10 overweight and 10 obese. Obese subjects had higher resting energy expenditure than normal individuals. Obese and non-obese individuals oxidized similar amounts of carbohydrates and lipids. Conclusions: BMI was not associated with the oxidation of lipids and carbohydrates in hospitalized patients. The amount of fat mass is associated with the total amount of carbohydrate and lipid oxidation.

Key words: indirect calorimetry, body mass index, substrate oxidation, lipids, carbohydrates.
\end{abstract}

\section{INTRODUCTION}

Over the last few years, the prevalence of obesity has been steadily increasing and this disease has been considered one of the most public health problems $(1,2)$. The positive energy balance resulting from life style modifications such as a reduced practice of physical activity and greater energy intake is the major contributor to the etiology of obesity (3). Energy balance is influenced by oxidation of macronutrients (proteins, carbohydrates and lipids) (4), and therefore the maintenance of body weight depends on the equilibrium between nutrient intake and substrate oxidation (5). Dietary planning aiming the weight loss, especially in a hospital care where diet is used as a tool for the treatment, it should meet the nutritional requirements of the individuals (6). Thus, the knowledge of which energy substrates are being utilized by the organism is an important tool for the nutritional treatment of obese patients in order to obtain an adequate food intake and weight loss.

The aim of the present study was to characterize substrate oxidation of hospitalized patients that belonged to different
Carolina Ferreira Nicoletti Roberta Deh Souza Santos Vivian M M Suen Julio Sérgio Marchini Carla Barbosa Nonino

Department of Internal Medicine, Faculdade de Medicina de Ribeirão Preto, Universidade de São Paulo. Brasil.

Dirigir la correspondencia a: Profesora Carla Barbosa N. Department of Internal Medicine, Faculdade de Medicina de Ribeirão Preto Universidade de São Paulo, Brazil. Phone: 551636024810 Fax: 551636336695 E-mail: carla@fmrp.usp.br

Este trabajo fue recibido el 4 de Septiembre de 2012 y aceptado para ser publicado el 14 de Enero de 2013.

ranges of Body Mass Index (BMI).

Subjects and methods

Hospitalized patients of both sexes admitted to various health care services of a public university hospital participated in the study. All patients received a standard $1800 \mathrm{kcal}$ diet consisting of $25 \%$ protein, $25 \%$ lipids and $50 \%$ carbohydrates. The patients underlying disease was not considered to prescribe the standard diet. The major reasons for hospitalization were orthopedic and gastrointestinal problems, hypertension, diabetes mellitus, and cardiac problems. All groups had similar proportions of these diseases. The study was approved by the Ethics Committee of the Hospital and all subjects gave written informed consent to participate. All patients were submitted to anthropometric and body composition evaluation and to indirect calorimetry for analysis of basal energy expenditure and substrate oxidation.

Weight, height and BMI were used for anthropometric assessment. BMI was calculated using weight $(\mathrm{kg})$ divided by squared height $(\mathrm{m})\left(\mathrm{BMI}=\mathrm{kg} / \mathrm{m}^{2}\right)$. The patients were weig- 
hed on a Filizola ${ }^{\circledR}$ digital platform scale with $300 \mathrm{~kg}$ capacity and $0.2 \mathrm{~kg}$ precision. Height was measured with vertical rod with $0.5 \mathrm{~cm}$ graduations. In parallel, body composition was determined by electrical bioimpedance using a Quantum BIA $101 \mathrm{Q}$ apparatus (RJL Systems).

Indirect calorimetry was determined during the morning after a fasting of 12 hours, with patient alert and at a controlled temperature room, as recommended by Warlich et al. (7). VO2 and VCO2 were measured with a Sensor Medics V29® calorimeter (Sensor Medics Corporation, Yorba Linda, Calif, USA) for 30 minutes. The instrument was calibrated using two gas cylinders: cylinder 1: $16 \% \mathrm{O}_{2}-3.80 \% \mathrm{CO}_{2}$ and cylinder 2: $26 \% \mathrm{O}_{2}-0 \% \mathrm{CO}_{2}$. Barometric calibration was performed using a Torricelli barometer and thermal calibration was performed by measuring the caloric release produced by burning $10 \mathrm{ml}$ $70 \%$ alcohol.

The formulas for the calculation of resting energy expenditure and substrates oxidation are presented below. The quantity of oxygen needed for a complete substrate oxidation $\left(\mathrm{VO}_{2}\right)$ and the quantity of carbon dioxide $\left(\mathrm{VCO}_{2}\right)$ produced per time unit were considered. Resting energy expenditure was calculated using the Weir formula (8) and the daily energy requirement was calculated using the result x $1440 \mathrm{~min}$ (kcal/ day). The urinary nitrogen fraction $\left(\mathrm{N}_{2}\right)$ was not considered because, according to Weir (8), the maximum error resulting from excluding it is less than 1 in 500 .

Energy requirement $(\mathrm{kcal} / \mathrm{min})=$ $3.491 \mathrm{VCO}_{2}(\mathrm{l} / \mathrm{min})+1.106 \mathrm{Vo}_{2}(\mathrm{l} / \mathrm{min})$ [Formula 1]

Rate of glucose oxidation $(\mathrm{g} / \mathrm{min})=$ $4.55 \mathrm{VCO}_{2}-3.21 \mathrm{Vo}_{2}-2.6 \mathrm{~N}_{2}$ [Formula 2]

Rate of lipid oxidation $(\mathrm{g} / \mathrm{min})=$ $1.67 \mathrm{Vo}_{2}-1.67 \mathrm{VCO}_{2}-1.92 \mathrm{~N}_{2}$ [Formula 3]
For data analysis, the individuals were divided into three groups according to $\mathrm{BMI}$ classification (9): group 1, eutrophy (BMI 18.5-24.9 kg/m²); group 2, overweight (BMI 25-29.9 $\left.\mathrm{kg} / \mathrm{m}^{2}\right)$ and group 3 , obesity $\left(\mathrm{BMI}>30 \mathrm{~kg} / \mathrm{m}^{2}\right)$.

\section{Statistical analyses}

Data are reported as mean \pm SD. The normal distribution of the data was determined by the Kolmogorov-Smirnov test. The differences between eutrophic, overweight and obese individuals were analyzed by ANOVA followed, when appropriate, by the Dunn post-test. The correlation between two variables was calculated by Pearson correlation test. The level of significance was set at $\mathrm{p} \leq 0.05$ in all analyses.

\section{RESULTS}

The sample consisted of 38 individuals (11 men and 27 women). Eighteen were eutrophic, 10, overweight and 10, obese. Data regarding the characterization of the sample and the results of indirect calorimetry are listed in table 1 . Obese individuals had a higher inspired oxygen rate $\left(\mathrm{VO}_{2}\right)$ and a greater resting energy expenditure $(1834 \pm 489 \mathrm{kcal})$ than eutrophic individuals $(1504 \pm 262 \mathrm{kcal})$. Overweight and obese individuals had higher energy expenditure per $\mathrm{kg}$ of body weight that eutrophic patients, however no difference was found in relation to expenditure per $\mathrm{kg}$ of FFM.

The obese and eutrophic individuals oxidized similar quantities of carbohydrates and lipids, whereas overweight individuals showed a greater sum of substrate oxidation (carbohydrates + lipids) than obese individuals.

$\mathrm{BMI}$ showed a low positive correlation with carbohydrate $(r=0.17)$ and lipid $(r=0.36)$ oxidation and with the sum of substrate oxidation $(r=0.36)$. There was a strong positive association between fat-free mass $(\mathrm{kg})$ and the sum of carbohydrate and lipid oxidation ( $r=0.67$ ) (figure 1 ).

Age, weight, $\mathrm{BMI}$ and indirect calorimetry results

\begin{tabular}{|c|c|c|c|}
\hline & Eutrophy $(n=18)$ & Overweight $(n=10)$ & Obesity $(n=10)$ \\
\hline Age (years) & $40 \pm 20$ & $49 \pm 12$ & $47 \pm 11$ \\
\hline Weight (kg) & $57 \pm 7$ & $71 \pm 5$ & $106 \pm 35^{*}$ \\
\hline $\mathrm{BMI}\left(\mathrm{kg} / \mathrm{m}^{2}\right)$ & $22 \pm 2$ & $28 \pm 2$ & $41 \pm 12 * \#$ \\
\hline $\mathrm{FM}(\mathrm{kg})$ & $16 \pm 4$ & $23 \pm 6$ & $48 \pm 30^{*}$ \\
\hline FFM (kg) & $39 \pm 6$ & $47 \pm 3$ & $56 \pm 12 * \#$ \\
\hline VCO2 (I/min) & $0.180 \pm 0.03$ & $0.178 \pm 0.02$ & $0.221 \pm 0.06$ \\
\hline VO2 (I/min) & $0.215 \pm 0.04$ & $0.221 \pm 0.02$ & $0.262 \pm 0.07^{*}$ \\
\hline RQ & $0.84 \pm 0.04$ & $0.81 \pm 0.07$ & $0.85 \pm 0.06$ \\
\hline REE (kcal/day) & $1504 \pm 262$ & $1533 \pm 163$ & $1834 \pm 489^{*}$ \\
\hline REE (kcal/ kg/day) & $26.2 \pm 3.3$ & $47.6 \pm 2^{*}$ & $55.6 \pm 3.2^{*}$ \\
\hline REE (kcal/ kg of FFM/day) & $36 \pm 4.6$ & $32.5 \pm 3.9$ & $32.1 \pm 5.2$ \\
\hline REE (kcal/ kg of FM/day) & $103 \pm 56$ & $70.1 \pm 16.6$ & $51.1 \pm 36.3^{*}$ \\
\hline Lip Ox. (g/day) & $82 \pm 26$ & $102 \pm 39$ & $97 \pm 50$ \\
\hline CHO Ox. (g/day) & $194 \pm 67$ & $152 \pm 96$ & $245 \pm 125$ \\
\hline Lip+CHO Ox. (g/day) & $276 \pm 60$ & $254 \pm 63$ & $342 \pm 112 \#$ \\
\hline $\begin{array}{l}\text { BMI: body mass index, FFM: fat-free mas } \\
\mathrm{VO}_{2} \text { : inspired oxygen volume, } \mathrm{RQ} \text { : respir } \\
\text { Values are reported as mean } \pm \mathrm{SD} \\
*: \mathrm{p}<0.05 \text { compared to eutrophy } \\
\#: p<0.05 \text { compared to overweight }\end{array}$ & $\begin{array}{l}\mathrm{SS}, \mathrm{VCO}_{2} \text { : expired ca } \\
\text { t, REE: resting energ }\end{array}$ & dation, CHO: carbohydra & \\
\hline
\end{tabular}




\section{DISCUSSION}

The data of the present study showed that obese individuals had greater energy expenditure than eutrophic individuals. These results are similar to those reported by Labayen et al. (5) when they compared the resting metabolic rate between obese and lean women. Authors have suggested that the greater energy expenditure of obese individuals seems to be correlated with both fat-free mass and adiposity $(10,11)$. Although all groups showed similar REE/kg of FFM, the finding of the present study may be associated with the larger amount of their fat-free mass, since this tissue is considered highly metabolically active (12).

It has been reported that obesity is a determinant of the reduction of lipid oxidation capacity during the basal period (13). In contrast, the results of the present study indicate that the rates of carbohydrate and lipid oxidation and their sum were similar for eutrophic and obese individuals. However, Labayen et al. (5) detected greater lipid oxidation in obese women, whereas in the present study there was no correlation between $\mathrm{BMI}$ and the oxidation of energy substrates.

All groups had similar values of the respiratory quotient showing that BMI did not affect the pattern of substrate oxidation. Other reports showed that obese women have greater lipid oxidation in order to obtain energy when compared to lean women (5).

A positive correlation was observed between fat-free mass and total substrate oxidation. It has been demonstrated that, in healthy individuals, fat-free mass is a determinant of lipid utilization (12). Other scientific findings have shown that body composition influences the rates of substrate oxidation, especially lipids (5). The storage of lipids in adipose tissue is determined by the quantity and type of macronutrients ingested (14) and therefore the evaluation of the rates of substrate oxidation can contribute to the elucidation of the etiology of obesity and guide the dietary treatment of hospitalized patients.

\section{CONCLUSION}

In the present study, BMI did not show association with lipid or carbohydrate oxidation. The quantity of fat-free mass was strongly related to the total quantity of oxidized carbohydrates and lipids.

\section{RESUMEN}

Introducción: El balance de energía se ve influenciado por la oxidación de macronutrientes (proteínas, carbohidratos y lípidos). Objetivo: Caracterizar la utilización de sustratos en sujetos con peso normal y obesos. Metodología: se realizó una impedancia bioeléctrica y una calorimetría indirecta para determinar la oxidación de carbohidratos y lípidos de pacientes hospitalizados. Los sujetos fueron divididos en tres grupos, el grupo 1: IMC 18,5-24,9 kg / m², grupo 2: IMC 25-29.9 kg / $\mathrm{m}^{2}$ y el grupo 3 : IMC> $30 \mathrm{~kg} / \mathrm{m}^{2}$. Los grupos de individuos

\section{FIGURE 1}

Correlation between substrate oxidation (g/day) and anthropometric measures.

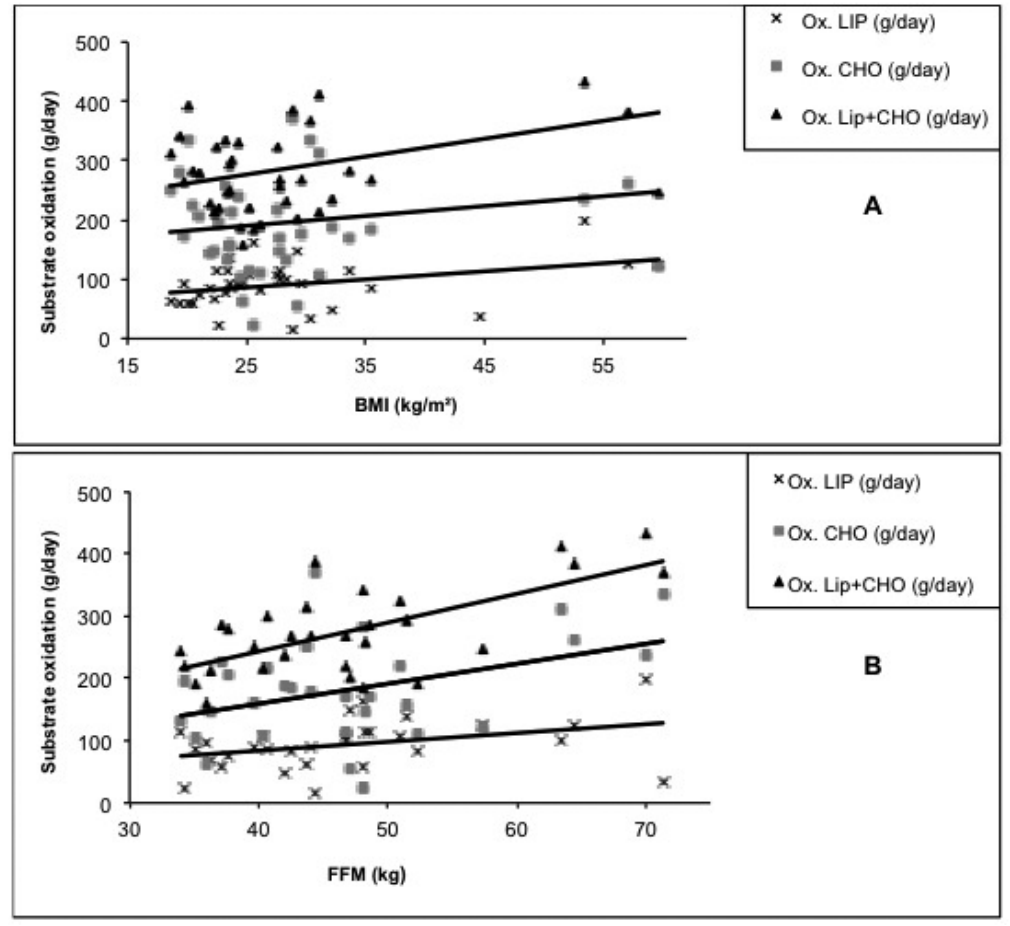

A: Body mass index $\left(\mathrm{kg} / \mathrm{m}^{2}\right) ;$ B: Fat free mass $(\mathrm{kg})$ 
se compararon mediante la prueba de ANOVA y, en algún caso, después de la prueba se aplicó el Dunn ( $p<0,05$ considerado significativo). Resultados: Se estudiaron 38 personas (11 hombres y 27 mujeres) con una edad media de 44,3 $\pm 16,5$ años; 18 normales, 10 con sobrepeso y 10 obesos. Los sujetos obesos tenían un mayor gasto energético en reposo que los individuos normales. Obesos y no obesos oxidan cantidades similares de carbohidratos y lípidos. Conclusiones: El índice de masa corporal no se asoció con la oxidación de los lípidos y carbohidratos en pacientes hospitalizados. La cantidad de masa sin grasa se asocia con la cantidad total de hidratos de carbono y oxidación de lípidos.

Palabras clave: calorimetría indirecta, índice de masa corporal, los sustratos de oxidación, lípidos, hidratos de carbono.

\section{REFERENCES}

1. Bonazzi $C L$ et al. A intervenção nutricional no pré e pós operatório da cirurgia bariátrica. Rev Bras Obes Nutr Emagrec 2007; 1(5):59-69.

2. Tremblay A, Doucet E. Obesity: a disease or a biological adaptation? Obes Rev 2000; (1): 27-35.

3. Bressan J, Hermsdorff HHM. A epidemia da obesidade: a causa, o tratamento e o ambiente. In: Moreira, E. A.M; Chiarello, P.G. Atenção Nutricional: Abordagem dietoterápica em adultos. Rio de Janeiro: Guanabara-Koogan, 2008, Cap.7, p.75-94.

4. Tentolouris N, Pavlatos S, Kokkinos A, Perrea D, Pagoni S, Katsilambros N. Diet-induced substrate oxidation are not different between lean and obese women after two different isocaloric meals, one rich in protein and one rich in fat. Metabolism Clin Experim 2008; 57:313-20.

5. Labayen I, Dıez N, Parra D, Gonzalez A, Martınez JA. Basal and postprandial substrate oxidation rates in obese women receiving two test meals with different protein content. Clin Nutr 2004; 23:571-8.

6. Nicoletti1 CF, Lima TP, Santos RDS, Tanaka NYY, Suen VM, Marchini JS, Nonino CB. The total amount of energy delivered by a Brazilian hospital catering does not meet patient requirements as measured by indirect calorimetry. Food Nutr Sci 2011; 2:60-5.

7. Wahrlich, $V$, Anjos, LA. Aspectos históricos e metodológicos da medição e estimativa da taxa metabólica basal: uma revisão da literatura. Cad, Saúde Pública 2001;17(4):801-17.

8. Weir JB. New methods for calculating metabolic rate with special reference to protein metabolism. J Physiol 1949; 109:1-9.

9. Obesity: preventing and managing the global epidemic. Report of a WHO consultation on obesity, Geneva: World Health Organization, 1998.

10. Ravussin E, Lillioja S, Knowler WC, Christin L, Freymond $D$, Abbott WG, et al. Reduced rate of energy expenditure as a risk factor for body-weight gain. N Engl J Med 1988; 318(8):467-72.

11. Luke A, Durazo-Avisu R, Cao G, Adeyesso A, Tayo B, Cooper $R$. Positive association between resting energy expenditure and weight gain in a lean adult population. Am J Clin Nutr 2006; 83(5):1076-81.

12. Poehlman ET. Energy expenditure and requirements in aging humans. J Nutr 1992; 122:2057-65.

13. Kelley $D E$, Mandarino LJ. Fuel selection in human skeletal muscle in insulin resistance: a reexamination. Diabetes 2000; 49:677-83.

14. Sonko BJ, Fennessey PV, Donnelly JE, Bessesen D, Sharp $T A$, Jacobsen DJ, Jones RJ, Hill JO. Ingested fat oxidation contributes $8 \%$ of 24- $h$ total energy expenditure in moderately obese subjects. J Nutr 2005;135: 2159-65. 